\title{
Effects of Novel Dinuclear Cisplatinum(II) Complexes on the Electric Properties of Human Breast Cancer Cells
}

\author{
Izabela Dobrzyńska • Elżbieta Skrzydlewska • \\ Zbigniew A. Figaszewski
}

Received: 13 June 2013/Accepted: 5 December 2013/Published online: 17 December 2013

(C) The Author(s) 2013. This article is published with open access at Springerlink.com

\begin{abstract}
The aim of this study was to determine the influence of cisplatin and novel dinuclear platinum(II) complexes on the electrical properties of the membrane and the level of lipid peroxidation in the human breast cancer cell lines MDA-MB-231 and MCF-7. The basal electrical surface properties of cells are known. Changes in cell function may affect these surface properties, and those changes can be detected by electrokinetic measurements. The surface charge density of the breast cancer cell lines MDA-MB-231 and MCF-7 were measured as a function of pH. A four-component equilibrium model was used to describe the interaction between the solution ions and the breast cancer cell surface. The experimental and the theoretical charge variation curves of the breast cancer cells at $\mathrm{pH} 2.5-9$ were in agreement. Measurements of the cellular malondialdehyde levels with high performance liquid chromatography were used to determine the extent of lipid peroxidation. The acid and base functional group concentrations and average association constants with hydroxyl ions were smaller in breast cancer cell membranes treated with cisplatin or novel dinuclear platinum(II) complexes compared with untreated cancer cells, and the average association constants with hydrogen ions were higher. The
\end{abstract}

I. Dobrzyńska $(\bowtie) \cdot$ Z. A. Figaszewski

Institute of Chemistry, University in Białystok, Al. Piłsudskiego

11/4, 15-443 Białystok, Poland

e-mail: izadob@uwb.edu.pl

E. Skrzydlewska

Department of Analytical Chemistry, Medical University of

Białystok, Mickiewicza 2, 15-230 Białystok, Poland

Z. A. Figaszewski

Laboratory of Electrochemical Power Sources, Faculty of Chemistry, University of Warsaw, Pasteur St. 1, 02-093 Warsaw, Poland levels of lipid peroxidation products in breast cancer cells treated with cisplatin or novel dinuclear platinum(II) complexes were also higher than in untreated cancer cells.

Keywords Surface charge density - Breast cancer cells lines (MDA-MB-231, MCF-7) · Cisplatin · Platinum(II) complex $\cdot$ Lipid peroxidation

\section{Introduction}

Biological membranes are essential boundaries within living cells. They are multi-component structures that are responsible for many of the physiological functions and electrical properties of cells. Defects in any of the membrane components can be manifest as changes in electric charge as well as clinical disorders (Benga and Holmes 1984; Gennis 1989).

At the interface of the cell and the environment there is an electric bilayer. The structure and properties of the layer are determined by the components of the outer membrane layer and by the equilibrium between its components and the substances present in the environment. Any perturbations in the actions of the cell are manifested by variations in the action of the electric bilayer. An essential property of the electric bilayer is its electrical charge, which can be altered by cancerous transformation or by various drugs. For these reasons, studies on the electric charge can provide information on the equilibrium within a membrane and between the membrane and its environment, both in physiological and in nonphysiological conditions (Dobrzyńska et al. 2013; Szachowicz-Petelska et al. 2012, 2013)

Structural positive and negative charge carriers determine the electrical charge of a membrane. Positive charge 
Fig. 1 Structure of novel platinum(II) complexes

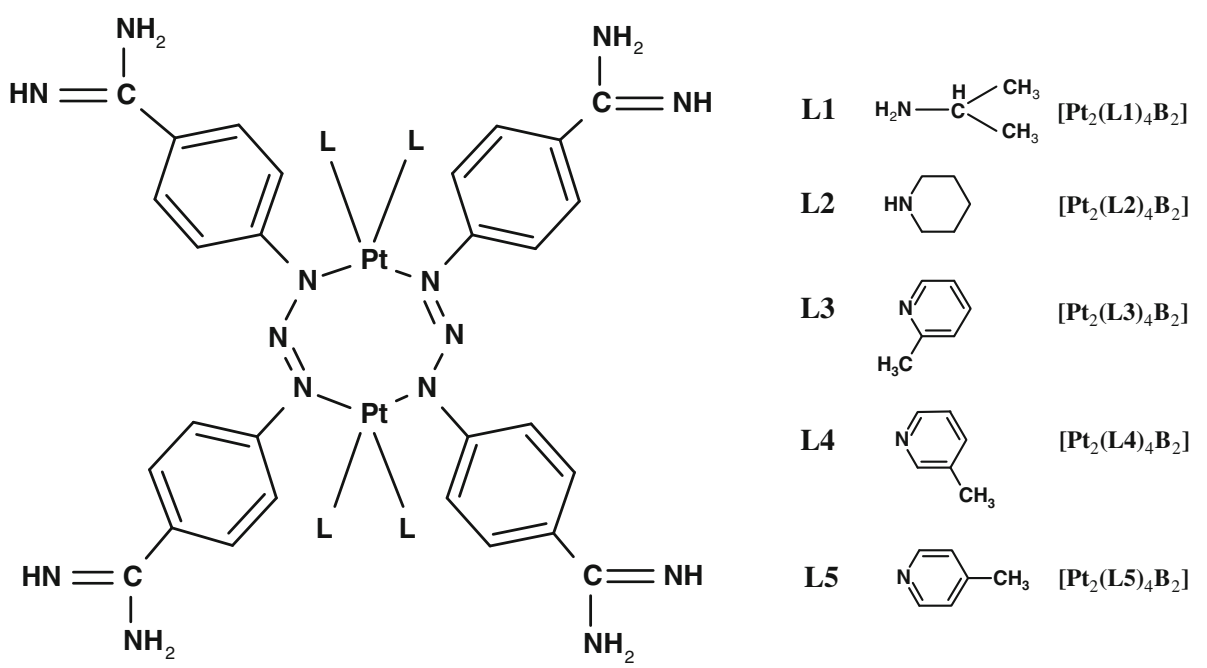

carriers include free amino groups of proteins and aminophospholopids. Negative charge carriers include phospholipids, especially phosphatidylserine, sialic acid, and free carboxyl groups of proteins. Determining the electric charge of cell membranes as a function of environmental $\mathrm{pH}$ and determining the acid $\left(C_{\mathrm{TA}}\right)$ and base $\left(C_{\mathrm{TB}}\right)$ functional group concentrations, and their average association constants with hydrogen $\left(K_{\mathrm{AH}}\right)$ or hydroxyl $\left(K_{\mathrm{BOH}}\right)$ ions can reveal changes caused by cancer transformation and treatment with drugs (Dobrzyńska et al. 2006).

Platinum drugs are important anticancer compounds. Cisplatin is widely used for the treatment of many cancers including testicular, ovarian, bladder, cervical, head, neck, esophageal, and small cell lung cancer (Rybak and Ramkumar 2007; Giaccone et al. 2004). Cisplatin reacts with cellular components that have nucleophilic sites such as DNA, RNA, proteins, membrane phospholipids, and thiolcontaining molecules. The interaction of cisplatin with genomic DNA leads to adduct formation including interand intra-strand DNA cross-links and DNA-protein crosslinks, which inhibit replication, transcription, and translation (Capeda et al. 2007).

The purpose of the work is to determine the influence of cisplatin and novel dinuclear platinum(II) complexes with the structure $\left[\mathrm{Pt}_{2} \mathrm{~L}_{4} \mathrm{~B}_{2}\right]$ (Fig. 1) on the electrical properties and lipid peroxidation of the cell membrane of human breast cancer cell lines MDA-MB-231 and MCF-7. Specifically, we tested platinum complexes $\mathrm{Pt}_{2}$ (isopropylamine $)_{4}(\text { berenil })_{2},\left[\mathrm{Pt}_{2}(\mathrm{~L} 1)_{4} \mathrm{~B}_{2}\right], \mathrm{Pt}_{2}$ (piperazine $)_{4}$ (berenil $)_{2}$, $\left[\mathrm{Pt}_{2}(\mathrm{~L} 2)_{4} \mathrm{~B}_{2}\right], \quad \mathrm{Pt}_{2}(2 \text {-picoline })_{4}$ (berenil $)_{2}, \quad\left[\mathrm{Pt}_{2}(\mathrm{~L} 3)_{4} \mathrm{~B}_{2}\right]$, $\mathrm{Pt}_{2}$ (3-picoline) $)_{4}$ (berenil $)_{2}, \quad\left[\mathrm{Pt}_{2}(\mathrm{~L} 4)_{4} \mathrm{~B}_{2}\right], \mathrm{Pt}_{2}$ (4-picoline) $)_{4}$ (berenil $)_{2}$, and $\left[\mathrm{Pt}_{2}(\mathrm{~L} 5)_{4} \mathrm{~B}_{2}\right]$. The quantitative description of cell membrane properties can aid in interpreting and understanding the processes that take place on biological membranes during cancer transformation.

\section{Theory}

The model, which has been presented in full detailed in previous study (Dobrzyńska et al. 2006), assumes that dependence of surface charge density of cell membrane on $\mathrm{pH}$ of electrolyte solution can be described with the help of four equilibria. There are two equilibria of negative groups, with the sodium and hydrogen ions and two equilibria of the positive groups, with the hydroxide and chloride ions. The $\mathrm{H}^{+}, \mathrm{OH}^{-} \mathrm{Na}^{+}$, and $\mathrm{Cl}^{-}$ions are adsorbed at the cell membrane (MDA-MB-231, MCF-7), and the adsorption equilibria (Eqs. 1-4) can by presented in the following form:

$\mathrm{A}^{-}+\mathrm{H}^{+} \Leftrightarrow \mathrm{AH}$

$\mathrm{A}^{-}+\mathrm{Na}^{+} \Leftrightarrow \mathrm{ANa}$

$\mathrm{B}^{+}+\mathrm{OH}^{-} \Leftrightarrow \mathrm{BOH}$

$\mathrm{B}^{+}+\mathrm{Cl}^{-} \Leftrightarrow \mathrm{BCl}$

The association constants of the $\mathrm{H}^{+} \mathrm{Na}^{+}, \mathrm{OH}^{-}$, and $\mathrm{Cl}^{-}$ ions with functional groups are expressed by the following equations:

$K_{\mathrm{AH}}=\frac{a_{\mathrm{AH}}}{a_{\mathrm{A}^{-}} \cdot a_{\mathrm{H}^{+}}}$

$K_{\mathrm{ANa}}=\frac{a_{\mathrm{ANa}}}{a_{\mathrm{A}^{-}} \cdot a_{\mathrm{Na}^{+}}}$

$K_{\mathrm{BOH}}=\frac{a_{\mathrm{BOH}}}{a_{\mathrm{B}^{+}} \cdot a_{\mathrm{OH}^{-}}}$

$K_{\mathrm{BCl}}=\frac{a_{\mathrm{BCl}}}{a_{\mathrm{B}^{+}} \cdot a_{\mathrm{Cl}^{-}}}$

where $K_{\mathrm{AH}}, K_{\mathrm{ANa}}, K_{\mathrm{BOH}}, K_{\mathrm{BCl}}$-association constants, $a_{\mathrm{A}^{-}}$, $a_{\mathrm{AH}}, a_{\mathrm{ANa}}, a_{\mathrm{B}^{+}}, a_{\mathrm{BOH}}$ and $a_{\mathrm{BCl}}$ - surface concentrations of corresponding groups on the membrane surface, $a_{\mathrm{H}^{+}}, a_{\mathrm{Na}^{+}}$, $a_{\mathrm{OH}^{-}}$and $a_{\mathrm{Cl}^{-}}$-corresponding concentrations in solution. 
Surface charge density $(\delta)$ is expressed as follows:

$\delta=\left(a_{\mathrm{B}^{+}}-a_{\mathrm{A}^{-}}\right) \cdot F$

where $F=96487[C / \mathrm{mol}]$ is the Faraday constant.

Functional group concentration balances are expressed as follows:

$C_{\mathrm{TA}}=a_{\mathrm{A}^{-}}+a_{\mathrm{AH}}+a_{\mathrm{ANa}}$

$C_{\mathrm{TB}}=a_{\mathrm{B}^{+}}+a_{\mathrm{BOH}}+a_{\mathrm{BCl}}$

where $C_{\mathrm{TA}}$ is the total surface concentrations of acidic groups and $C_{\mathrm{TB}}$ is the total surface concentrations of basic groups.

Elimination of $a_{\mathrm{A}^{-}}, a_{\mathrm{AH}}, a_{\mathrm{B}^{+}}$, and $a_{\mathrm{BOH}}$ values from above equation yields the following formula:

$$
\begin{aligned}
\frac{\delta}{F}= & \frac{C_{\mathrm{TB}} \cdot a_{\mathrm{H}^{+}}}{a_{\mathrm{H}^{+}}\left(1+K_{\mathrm{BCl}} \cdot a_{\mathrm{Cl}^{-}}\right)+K_{\mathrm{BOH}} \cdot K_{\mathrm{w}}} \\
& -\frac{C_{T A}}{K_{\mathrm{AH}} \cdot a_{\mathrm{H}^{+}}+K_{\mathrm{ANa}} \cdot a_{\mathrm{Na}^{+}}+1}
\end{aligned}
$$

It is difficult to solve Eq. 12 and determine the $K_{\mathrm{AH}}, K_{\mathrm{BOH}}$, $K_{\mathrm{ANa}}$, and $K_{\mathrm{BCl}}$ constants. In cases of high or low hydrogen ion concentrations Eq. 12 can be simplified to linear equations. In the range of high $\mathrm{H}^{+}$concentration, the numerator of each term in Eq. 12 can be divided by the denominator leaving two initial terms only. These operations yield the linear equation in the $a_{\mathrm{H}^{+}}$and $\frac{\delta}{F} a_{\mathrm{H}^{+}}$coordinate system;

$$
\begin{aligned}
\frac{\delta}{F} a_{\mathrm{H}^{+}}= & \frac{C_{\mathrm{TB}}}{1+K_{\mathrm{BCl}} \cdot a_{\mathrm{Cl}^{-}}} \cdot a_{\mathrm{H}^{+}} \\
& -\left(\frac{K_{\mathrm{BOH}} \cdot K_{\mathrm{w}} \cdot C_{\mathrm{TB}}}{\left(1+K_{\mathrm{BCl}} \cdot a_{\mathrm{Cl}^{-}}\right)^{2}}+\frac{C_{\mathrm{TA}}}{K_{\mathrm{AH}}}\right)
\end{aligned}
$$

In graphical representation, the slope and the intercept can be easily extracted. At low $\mathrm{H}^{+}$ion concentration Eq. 12 simplified to:

$$
\begin{aligned}
\frac{\delta}{F}= & \frac{C_{\mathrm{TB}} \cdot a_{\mathrm{H}^{+}}}{K_{\mathrm{BOH}} \cdot K_{\mathrm{w}}+a_{\mathrm{H}^{+}}\left(1+K_{\mathrm{BCl}} \cdot a_{\mathrm{Cl}^{-}}\right)} \\
& -\frac{C_{\mathrm{TA}}}{K_{\mathrm{ANa}} \cdot a_{\mathrm{Na}^{+}}+1+K_{\mathrm{AH}} \cdot a_{\mathrm{H}^{+}}}
\end{aligned}
$$

The numerator of each term should be divided by the denominator leaving two initial terms only. These operations yield a linear equation in the $a_{\mathrm{H}^{+}}^{-1}$ and $\frac{\delta}{F} a_{\mathrm{H}^{+}}^{-1}$ coordinate system:

$$
\begin{aligned}
\frac{\delta}{F} a_{\mathrm{H}^{+}}^{-1}= & \frac{-C_{\mathrm{TA}} \cdot a_{\mathrm{H}^{+}}^{-1}}{1+K_{\mathrm{ANa}} \cdot a_{\mathrm{Na}^{+}}} \\
& +\left(\frac{C_{\mathrm{TB}}}{K_{\mathrm{BOH}} \cdot K_{\mathrm{W}}}+\frac{K_{\mathrm{AH}} \cdot C_{\mathrm{TA}}}{\left(1+K_{\mathrm{ANa}} \cdot a_{\mathrm{Na}^{+}}\right)^{2}}\right)
\end{aligned}
$$

In graphical representation, the slope and the intercept can be easily extracted.

The coefficients estimated from the linear regression can be used to determine $C_{\mathrm{TA}}, C_{\mathrm{TB}}, K_{\mathrm{AH}}$, and $K_{\mathrm{BOH}}$. The points included in the regression must be carefully selected, both in high and low $\mathrm{pH}$ ranges. Defining the value of these parameters permits the calculation of the theoretical cell membrane surface charge from Eq. 12 for comparison to experimental date.

\section{Materials and Methods}

\section{Cell Culture}

The human breast cancer cell lines MCF7 and MDA-MB231 (derived by the American Type Culture Collection) were maintained in Dulbecco's modified Eagle's medium containing $10 \%$ fetal bovine serum, $50 \mathrm{U} / \mathrm{ml}$ penicillin, and $50 \mu \mathrm{g} / \mathrm{ml}$ streptomycin. Cells were cultured in a humidified atmosphere with $5 \% \mathrm{CO}_{2}$ at $37{ }^{\circ} \mathrm{C}$. The cells reached confluence after three days and were used for the assays.

Cell suspensions, $1 \times 10^{6}$ cells $/ \mathrm{ml}$ in $6 \mathrm{ml}$ of culture medium, were incubated with or without the experimental compounds in cell culture plates. The platinum(II) complexes $\left[\mathrm{Pt}_{2}(\mathrm{~L} 1)_{4} \mathrm{~B}_{2}, \mathrm{Pt}_{2}(\mathrm{~L} 2)_{4} \mathrm{~B}_{2}, \mathrm{Pt}_{2}(\mathrm{~L} 3)_{4} \mathrm{~B}_{2}, \mathrm{Pt}_{2}(\mathrm{~L} 4)_{4} \mathrm{~B}_{2}\right.$, and $\mathrm{Pt}_{2}(\mathrm{~L} 5)_{4} \mathrm{~B}_{2}$ ] and cisplatin were added to the cultured cells to give a final concentration $20 \mu \mathrm{M}$. Control cells were incubated without test compounds. Cells from each cell line were harvested after $12 \mathrm{~h}$ of incubation.

\section{Lipid Peroxidation}

The extent of lipid peroxidation in cells was assayed by measuring malondialdehyde (MDA) levels. MDA levels were estimated by performing a condensation reaction with thiobarbituric acid (TBA) with MDA. The products were separated by high performance liquid chromatography (HPLC). In brief, $0.75 \mathrm{ml}$ phosphate acid solution $(0.44 \mathrm{M})$ and $0.25 \mathrm{ml}$ freshly prepared TBA solution (42 $\mathrm{mM})$ were added to $0.5 \mathrm{ml}$ diluted cells, and the mixture was incubated for $60 \mathrm{~min}$ at $100{ }^{\circ} \mathrm{C}$. After the mixture cooled, $0.5 \mathrm{ml}$ was neutralized with $0.5 \mathrm{ml} 1 \mathrm{M}$ methanol-1 $\mathrm{M} \mathrm{NaOH}$ (45.5:4.5; v:v). After centrifugation, $30 \mu \mathrm{l}$ of the solution was injected into the chromatographic column (RP18). Separation was carried out with an isocratic elution of $40 \%$ methanol and $60 \%$ phosphate buffer $\mathrm{pH}$ 7.0. Detection was performed with a spectrofluorometric detector $\left(\lambda_{\text {excitation }}=\right.$ $532 \mathrm{~nm} ; \lambda_{\text {emission }}=553 \mathrm{~nm}$ ). The concentration of MDA was expressed in nmoles TBA-rs/ml in the cell lysates.

\section{Electrochemical Method}

In order to determine the surface charge density of cell membranes, cells were suspended in $0.015 \mathrm{M} \mathrm{NaCl}$ in a measuring vessel, and electrophoretic mobility was measured using Zetasizer Nano ZS apparatus (Malvern 


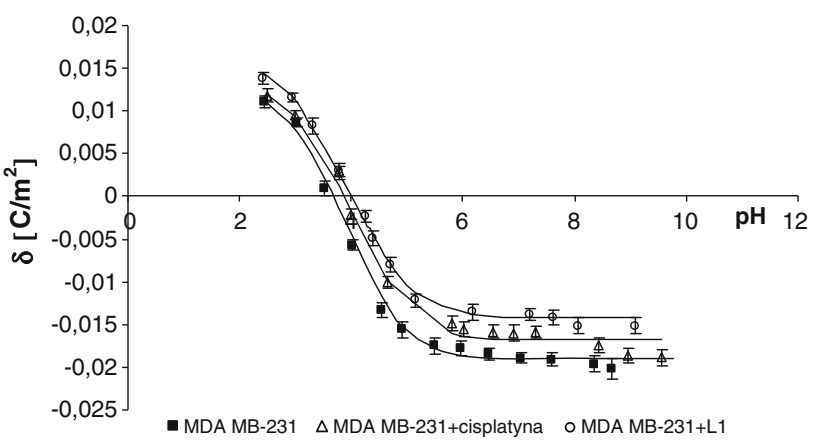

Fig. 2 The membrane charge density of MDA-MB-231 breast cancer cells with and without treatment with cisplatin and $\mathrm{Pt}_{2}(\mathrm{~L} 1)_{4} \mathrm{~B}_{2}$. The experimental values are marked by points and the theoretical ones by line

Instruments). The measurements were carried out as a function of $\mathrm{pH}$. The surface charge density was determined by the equation: $\sigma=\eta u / d$ in which $u$ was the electrophoretic mobility, $\eta$ was the viscosity of the solution, and $d$ was the diffuse layer thickness (Krysiński and Tien 1986).

The diffuse layer thickness was determined from the formula (Barrow 1996) $d=\sqrt{\frac{\varepsilon \cdot \varepsilon_{0} \cdot R \cdot T}{2 \cdot F^{2} \cdot I}}$, where $R$ was the gas constant, $T$ was the temperature, $F$ was the Faraday number, $I$ was the ionic strength of $0.9 \% \mathrm{NaCl}$, and $\varepsilon \varepsilon_{\mathrm{o}}$ was the permeability electric medium.

\section{Statistical Analysis}

The data obtained in this study were expressed as mean $\pm \mathrm{SD}$. The data were analyzed using one-way ANOVA with Scheffe's $F$ test for multiple comparisons. The values for $P<0.05$ were considered significant.

\section{Results and Discussion}

Chemotherapy plays an important role in the treatment of breast cancer, a leading cause of cancer death among women. This study was conducted to examine the effects of new chemotherapeutic complexes on the electrical properties and extent of lipid peroxidation in human breast cancer cells.

The experimental and theoretical surface charge densities of the cell membrane measured as a function of $\mathrm{pH}$ are presented in Figs. 1, 2, 3, and 4. The experimental measurements were indicated by points, and the theoretical values were represented as curves. The surface charge density dependencies of MDA-MB and MCF-7 cells on $\mathrm{pH}$ produced similarly, shaped curves for all studies.

The treatment of MDA-MB cells with cisplatin or novel dinuclear platinum(II) complexes caused a decrease in

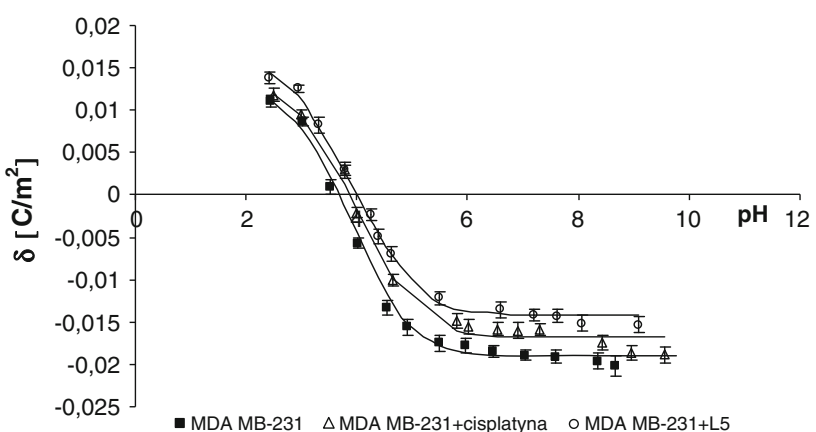

Fig. 3 The membrane charge density of MDA-MB-231 breast cancer cells with and without treatment with cisplatin and $\mathrm{Pt}_{2}(\mathrm{~L} 5)_{4} \mathrm{~B}_{2}$. The experimental values are marked by points and the theoretical ones by line

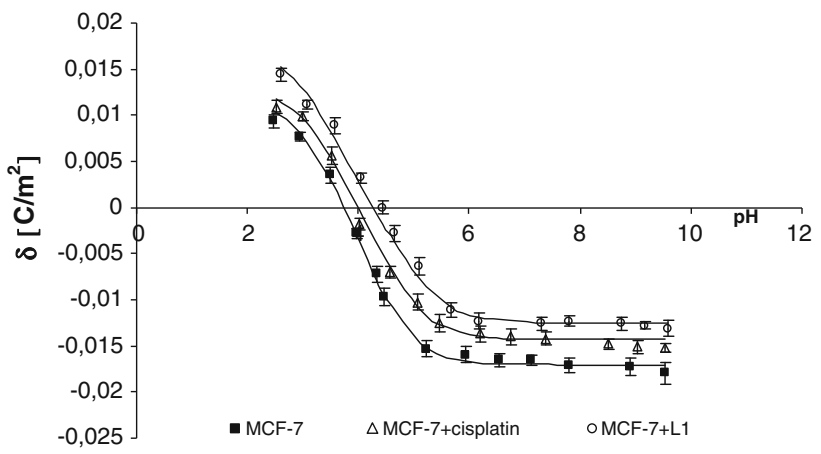

Fig. 4 The membrane charge density of MCF-7 breast cancer cells with and without treatment with cisplatin and $\mathrm{Pt}_{2}(\mathrm{~L} 1)_{4} \mathrm{~B}_{2}$. The experimental values are marked by points and the theoretical ones by line

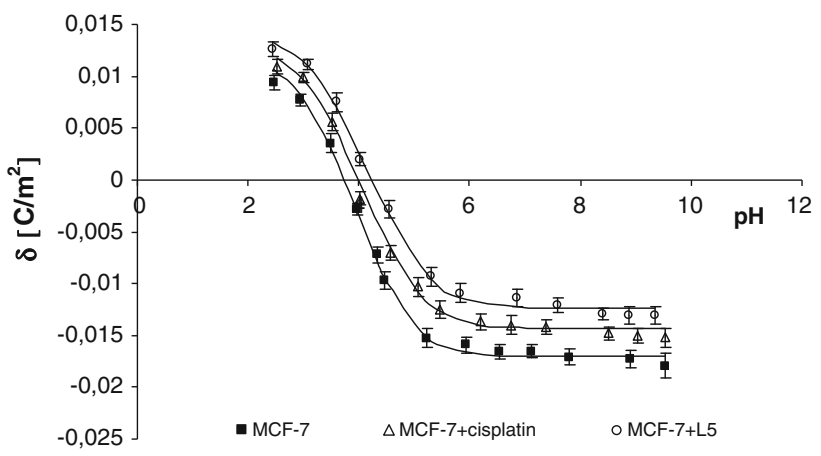

Fig. 5 The membrane charge density of MCF-7 breast cancer cells with and without treatment with cisplatin and $\mathrm{Pt}_{2}(\mathrm{~L} 5)_{4} \mathrm{~B}_{2}$. The experimental values are marked by points and the theoretical ones by line

negative charge at high/low $\mathrm{pH}$ values compared with untreated cells (Figs. 2, 3). The isoelectric point of MDAMB cell membranes treated with cisplatin or novel dinuclear platinum(II) complexes shifted to higher $\mathrm{pH}$ values compared with untreated MDA-MB cell membranes. Similarly, administering cisplatin or novel dinuclear platinum(II) complexes to MCF-7 cells caused a decrease in 
Table 1 Effects of cisplatin and novel dinuclear platinum(II) complexes on $C_{\mathrm{TA}}, C_{\mathrm{TB}}, K_{\mathrm{AH}}$, and $K_{\mathrm{BOH}}$ of MDA-MB-221 breast cancer cells

\begin{tabular}{|c|c|c|c|c|}
\hline \multirow[t]{2}{*}{ Groups } & \multicolumn{4}{|l|}{ Parameters } \\
\hline & $C_{\mathrm{TA}}\left(10^{-7} \mathrm{~mol} / \mathrm{m}^{2}\right)$ & $C_{\mathrm{TB}}\left(10^{-7} \mathrm{~mol} / \mathrm{m}^{2}\right)$ & $K_{\mathrm{AH}}\left(\mathrm{m}^{3} / \mathrm{mol}\right)$ & $K_{\mathrm{BOH}}\left(10^{7} \mathrm{~m}^{3} / \mathrm{mol}\right)$ \\
\hline MDA-MB-231 & $1.90 \pm 0.08$ & $1.31 \pm 0.06$ & $18.80 \pm 1.08$ & $4.97 \pm 0.18$ \\
\hline MDA-MB-231 + cisplatin & $1.58 \pm 0.04^{\mathrm{a}}$ & $1.48 \pm 0.05^{\mathrm{a}}$ & $22.81 \pm 1.10^{\mathrm{a}}$ & $3.97 \pm 0.12^{\mathrm{a}}$ \\
\hline MDA-MB-231 $+\left[\mathrm{Pt}_{2}(\mathrm{~L} 1)_{4} \mathrm{~B}_{2}\right]$ & $1.43 \pm 0.07^{\mathrm{a}, \mathrm{b}}$ & $1.63 \pm 0.06^{\mathrm{a}, \mathrm{b}}$ & $32.80 \pm 1.10^{\mathrm{a}, \mathrm{b}}$ & $3.62 \pm 0.19^{\mathrm{a}, \mathrm{b}}$ \\
\hline MDA-MB-231 $+\left[\mathrm{Pt}_{2}(\mathrm{~L} 2)_{4} \mathrm{~B}_{2}\right]$ & $1.37 \pm 0.10^{\mathrm{a}, \mathrm{b}}$ & $1.69 \pm 0.08^{\mathrm{a}, \mathrm{b}}$ & $35.41 \pm 1.11^{\mathrm{a}, \mathrm{b}}$ & $3.54 \pm 0.12^{\mathrm{a}, \mathrm{b}}$ \\
\hline MDA-MB-231 $+\left[\mathrm{Pt}_{2}(\mathrm{~L} 3)_{4} \mathrm{~B}_{2}\right]$ & $1.48 \pm 0.10^{\mathrm{a}}$ & $1.51 \pm 0.09^{\mathrm{a}}$ & $28.89 \pm 1.10^{\mathrm{a}, \mathrm{b}}$ & $3.81 \pm 0.11^{\mathrm{a}}$ \\
\hline MDA-MB-231 $+\left[\mathrm{Pt}_{2}(\mathrm{~L} 4)_{4} \mathrm{~B}_{2}\right]$ & $1.41 \pm 0.10^{\mathrm{a}, \mathrm{b}}$ & $1.59 \pm 0.10^{\mathrm{a}}$ & $30.72 \pm 1.10^{\mathrm{a}, \mathrm{b}}$ & $3.65 \pm 0.11^{\mathrm{a}, \mathrm{b}}$ \\
\hline MDA-MB-231 $+\left[\mathrm{Pt}_{2}(\mathrm{~L} 5)_{4} \mathrm{~B}_{2}\right]$ & $1.45 \pm 0.06^{\mathrm{a}, \mathrm{b}}$ & $1.62 \pm 0.05^{\mathrm{a}, \mathrm{b}}$ & $32.46 \pm 1.10^{\mathrm{a}, \mathrm{b}}$ & $3.67 \pm 0.10^{\mathrm{a}, \mathrm{b}}$ \\
\hline
\end{tabular}

$p<0.05$

${ }^{\text {a }}$ Compared with cancer cell (MDA-MB-231)

b Compared with cisplatin

negative charge at high $\mathrm{pH}$ values and an increase in positive charge at low $\mathrm{pH}$ values compared with untreated MCF-7 cells (Figs. 4, 5). The isoelectric point of cisplatin or novel dinuclear platinum(II) complex treated MCF-7 cell membranes shifted to higher $\mathrm{pH}$ values compared with untreated MCF-7 cell membranes.

Mathematical calculations based on the four equilibria model described the adsorption of electrolyte ions on a cell surface membrane. We used this to enable quantitative evaluations of the membrane parameters. The total concentrations of functional $C_{\mathrm{TA}}$ and $C_{\mathrm{TB}}$ groups was determined for treated and untreated breast cancer cell lines MDA-MB and MCF-7. The average association constants $K_{\mathrm{AH}}$ and $K_{\mathrm{BOH}}$ were calculated based on Eqs. 13 and 14 . The $C_{\mathrm{TA}}, C_{\mathrm{TB}}, K_{\mathrm{AH}}$, and $K_{\mathrm{BOH}}$ constants resulting from the calculations were substituted into Eq. 12 yielding the theoretical curve. Experimental points and theoretical curves are presented in Figs. 1, 2, 3, and 4. The theoretical and experimental surface charge density values agreed.

The experimental results indicated that cisplatin or novel dinuclear platinum(II) complexes caused a decrease in negative charge at the MDA-MB cell surface. This corresponded to a decreased surface concentration of $C_{\mathrm{TA}}$ groups. Changes in functional group composition of the MDA-MB cell membrane can be due to the appearance or disappearance of new functional groups resulting from the reactions with cisplatin or novel dinuclear platinum(II) complexes. Treatment with cisplatin or novel dinuclear platinum(II) complexes increased the association constants of negatively charged $K_{\mathrm{AH}}$ and decreased the association constants of positively charged $K_{\mathrm{BOH}}$ groups (Table 1 ).

The experimental results indicate that cisplatin (new complexes) caused a decrease in negative charge numbers at the MCF-7 cell surface. This corresponded to a decrease surface concentration of $C_{\mathrm{TA}}$ and an increased surface concentration of $C_{\mathrm{TB}}$. Similar to MDA-MB cells, changes in functional group composition on the membrane surface was due to the appearance or disappearance of functional groups on the MCF-7 cell surface. Cisplatin or new complexes increased the association constants of negatively charged $K_{\mathrm{AH}}$ and decreased the association constants of positively charged $K_{\mathrm{BOH}}$ groups (Table 2). Higher changes were observed after treatment with novel dinuclear platinum(II) complexes compared with cisplatin.

Table 3 shows levels of the lipid peroxidation product MDA measured by HPLC. The treatment of MDA-MB-231 cells with cisplatin or the cisplatin complexes caused an increase in the MDA level compared with untreated cancer cells. Similarly, the treatment of MCF-7 cells with cisplatin or other cisplatin complexes caused an increase in the MDA level compared with untreated cancer cells.

Reactive oxygen species (ROS) have been reported to play an important role in apoptosis by regulating the activity of certain enzymes involved in the cell death pathway. Many anticancer agents have been found to induce cancer cell apoptosis by increasing ROS (Chen et al. 2008). Growing evidences suggest that generation of ROS is an important cellular event induced by chemotherapeutic drugs. Nonpublished our data shown significant increase in ROS level in the breast cancer cells after berenil-platinum(II) complexes. Moreover, it was shown that berenil-platinum(II) complexes are more potent antiproliferative agents than cisplatin. The degree to which these compounds inhibited cell growth breast cancer cells was generally consistent with their relative DNA-binding affinity, and detection of apoptosis by a fluorescent microscopy assay revealed that novel dinuclear platinum(II) complexes inhibited the proliferation of MCF-7 breast cancer cells by increasing the number of apoptotic and necrotic cells (Bielawski et al. 2010; Poplawska et al. 2009). These complexes influence cellular metabolic pathways through the expression of transcription factor NFkB and in consequence increased expression MAPkinases (ERK1/2, p38) and IGF-1 and B1 integrin receptor (Bielawska et al. 2010). 
Table 2 Effects of cisplatin and novel dinuclear platinum(II) complexes on $C_{\mathrm{TA}}, C_{\mathrm{TB}}, K_{\mathrm{AH}}$, and $K_{\mathrm{BOH}}$ of MCF-7 breast cancer cells

\begin{tabular}{|c|c|c|c|c|}
\hline \multirow[t]{2}{*}{ Groups } & \multicolumn{4}{|l|}{ Parameters } \\
\hline & $C_{\mathrm{TA}}\left(10^{-7} \mathrm{~mol} / \mathrm{m}^{2}\right)$ & $C_{\mathrm{TB}}\left(10^{-7} \mathrm{~mol} / \mathrm{m}^{2}\right)$ & $K_{\mathrm{AH}}\left(\mathrm{m}^{3} / \mathrm{mol}\right)$ & $K_{\mathrm{BOH}}\left(10^{7} \mathrm{~m}^{3} / \mathrm{mol}\right)$ \\
\hline MCF-7 & $1.73 \pm 0,01$ & $1.16 \pm 0,09$ & $26.81 \pm 1.10^{\mathrm{a}}$ & $2.92 \pm 0.11^{\mathrm{a}}$ \\
\hline MCF-7 + cisplatin & $1.43 \pm 0.50^{\mathrm{a}}$ & $1.31 \pm 0.05^{\mathrm{a}}$ & $32.80 \pm 1.11^{\mathrm{a}}$ & $3.17 \pm 0.10^{\mathrm{a}}$ \\
\hline $\mathrm{MCF}-7+\left[\mathrm{Pt}_{2}(\mathrm{~L} 1)_{4} \mathrm{~B}_{2}\right]$ & $1.25 \pm 0.06^{\mathrm{a}, \mathrm{b}}$ & $1.71 \pm 0.06^{\mathrm{a}, \mathrm{b}}$ & $48.47 \pm 1.10^{\mathrm{a}, \mathrm{b}}$ & $3.82 \pm 0.12^{\mathrm{a}, \mathrm{b}}$ \\
\hline $\mathrm{MCF}-7+\left[\mathrm{Pt}_{2}(\mathrm{~L} 2)_{4} \mathrm{~B}_{2}\right]$ & $1.31 \pm 0.05^{\mathrm{a}, \mathrm{b}}$ & $1.54 \pm 0.05^{\mathrm{a}, \mathrm{b}}$ & $38.48 \pm 1.12^{\mathrm{a}, \mathrm{b}}$ & $3.98 \pm 0.14^{\mathrm{a}, \mathrm{b}}$ \\
\hline $\mathrm{MCF}-7+\left[\mathrm{Pt}_{2}(\mathrm{~L} 3)_{4} \mathrm{~B}_{2}\right]$ & $1.30 \pm 0.06^{\mathrm{a}, \mathrm{b}}$ & $1.59 \pm 0.06^{\mathrm{a}, \mathrm{b}}$ & $37.52 \pm 1.15^{\mathrm{a}, \mathrm{b}}$ & $3.93 \pm 0.16^{\mathrm{a}, \mathrm{b}}$ \\
\hline $\mathrm{MCF}-7+\left[\mathrm{Pt}_{2}(\mathrm{~L} 4)_{4} \mathrm{~B}_{2}\right]$ & $1.32 \pm 0.05^{\mathrm{a}, \mathrm{b}}$ & $1.60 \pm 0.07^{\mathrm{a}, \mathrm{b}}$ & $40.41 \pm 1.11^{\mathrm{a}, \mathrm{b}}$ & $3.87 \pm 0.12^{\mathrm{a}, \mathrm{b}}$ \\
\hline $\mathrm{MCF}-7+\left[\mathrm{Pt}_{2}(\mathrm{~L} 5)_{4} \mathrm{~B}_{2}\right]$ & $1.32 \pm 0.04^{\mathrm{a}, \mathrm{b}}$ & $1.61 \pm 0.04^{\mathrm{a}, \mathrm{b}}$ & $39.54 \pm 1.16^{\mathrm{a}, \mathrm{b}}$ & $3.92 \pm 0.11^{\mathrm{a}, \mathrm{b}}$ \\
\hline
\end{tabular}

$p<0.05$

${ }^{\mathrm{a}}$ Compared with cancer cell (MCF-7)

b Compared with cisplatin

Table 3 Effect of cisplatin and novel dinuclear platinum(II) complexes on the lipid peroxidation products measured as MDA in the breast cancer cell lines MDA-MB-231 and MCF-7

\begin{tabular}{llc}
\hline Groups & MDA-MB-231 & MCF-7 \\
\hline Control & $1.25 \pm 0.04$ & $10.32 \pm 0.43$ \\
Cisplatin & $1.43 \pm 0.04^{\mathrm{a}}$ & $13.75 \pm 0.51^{\mathrm{a}}$ \\
{$\left[\mathrm{Pt}_{2}(\mathrm{~L} 1)_{4} \mathrm{~B}_{2}\right]$} & $1.86 \pm 0.05^{\mathrm{a}, \mathrm{b}}$ & $9.82 \pm 0.41^{\mathrm{b}}$ \\
{$\left[\mathrm{Pt}_{2}(\mathrm{~L} 2)_{4} \mathrm{~B}_{2}\right]$} & $2.47 \pm 0.08^{\mathrm{a}, \mathrm{b}}$ & $8.95 \pm 0.36^{\mathrm{a}, \mathrm{b}}$ \\
{$\left[\mathrm{Pt}_{2}(\mathrm{~L} 3)_{4} \mathrm{~B}_{2}\right]$} & $1.43 \pm 0.05^{\mathrm{a}}$ & $15.43 \pm 0.67^{\mathrm{a}, \mathrm{b}}$ \\
{$\left[\mathrm{Pt}_{2}(\mathrm{~L} 4)_{4} \mathrm{~B}_{2}\right]$} & $2.04 \pm 0.05^{\mathrm{a}, \mathrm{b}}$ & $8.29 \pm 0.37^{\mathrm{a}, \mathrm{b}}$ \\
{$\left[\mathrm{Pt}_{2}(\mathrm{~L} 5)_{4} \mathrm{~B}_{2}\right]$} & $2.30 \pm 0.08^{\mathrm{a}, \mathrm{b}}$ & $10.12 \pm 0.45^{\mathrm{b}}$ \\
\hline
\end{tabular}

$p<0.05$

${ }^{\text {a }}$ Compared with cancer cell (MDA-MB-231 or MCF-7)

b Compared with cisplatin

Cell membrane charge is affected by sialic acid present on glycolipids and glycoproteins and approximately $70 \%$ of total sialic acid is found on the cell surface. It has been proposed that sialic acid also influences the surface concentration of $C_{\mathrm{TA}}$ and $C_{\mathrm{TB}}$ groups, as well as association constants with the positive and negative groups during cancer transformation and after drug treatment. The literature indicates that during cancer transformation, sialic acid content on glycolipids and glycoproteins increases (Oliva et al. 2006; Weigelt et al. 2005; Narayanan 1994). The decrease of sialic acid on cancer cells after of cisplatin or other drug treatments may be associated with an enhanced immune response of the host. It has been suggested that the loss of sialic acid decreases the surface concentration of $C_{\mathrm{TA}}$ groups and may lead to increased cell deformity and enhanced susceptibility to phagocytosis (Nicol and Prasad 2002).

Platinum(II) complexes preferentially attack membrane proteins. These complexes can also interact with phospholipids, but the bonds are relatively weak and reversible (Gea Speelmans et al. 1996; Chu 1994). The unstable interaction with phospholipids provokes changes in phospholipid conformation and in the structure and permeability of the membranes. The bond between platinum and monomeric proteins also provokes conformation changes and perturbs self-association of the monomers. The binding of platinum(II) complexes to the actin may be one of the reasons causes cell death by cross-linking and aggregating monomers, which depolymerizes microfilaments (Szachowicz-Petelska et al. 2001). Literature date show that at the molecular level, actin is indeed remodeled considerably in cisplatin-sensitive and cisplatin-resistant cells (Sharma et al. 2012). The increase in the number of apoptotic and necrotic cells after dinuclear platinum(II) complexes confirm this suggestion, but the reason may be also connected with changes in metabolic pathway through the affect NFkB signaling (Poplawska et al. 2009).

Proteins bound to DNA react with membrane phospholipids. Their activity in DNA replication, transcription, and recombination is modified by acidic phospholipids (Sekimizu 1994). It is suggested that the changes in membrane composition are connected with the changes in cell membrane charge. In conclusion, new platinum(II) complexes disturb the electrical properties and lipid peroxidation of cell membranes more effectively than cisplatin.

The constants $C_{\mathrm{TA}}, C_{\mathrm{TB}}, K_{\mathrm{AH}}$, and $K_{\mathrm{BOH}}$ are suitable for monitoring the changes caused by platinum(II) drugs. Therefore, evaluating the effects of anticancer drugs on the cell membrane may be an important component in future studies of cancer cell biology.

Acknowledgments This work was supported by a grant from the Polish Committee of Scientific Research No. NN405268837. 
Open Access This article is distributed under the terms of the Creative Commons Attribution License which permits any use, distribution, and reproduction in any medium, provided the original author(s) and the source are credited.

\section{References}

Barrow GM (1996) Physical chemistry. McGraw-Hill, Inc., New York

Benga G, Holmes RP (1984) Interactions between components in biological membranes and their implications for membrane function. Prog Biophys Mol Biol 43:195-257

Bielawska A, Poplawska B, Surazynski A, Czarnomysy R, Bielawski K (2010) Cytotoxic efficacy of a novel dinuclear platinum(II) complex in human breast cancer cells. Eur J Pharmacol 643:34-41

Bielawski K, Bielawska A, Poplawska B, Surazynski A, Czarnomysy $R$ (2010) The effect of a novel dinuclear platinum complex with berenil and 2-picoline ligands on growth of human breast cancer cells. Acta Pol Pharm 67(6):609-614

Capeda V, Fuertes MA, Castilla J, Alonso C, Quevedo C, Perez JM (2007) Biochemical mechanisms of cisplatin cytotoxicity. Anticancer Agents Med Chem 7:3-18

Chen W, Zhao Z, Li L, Wu B, Chen S, Zhou H, Wang Y, Li YQ (2008) Hispolon induces apoptosis in human gastric cancer cells through a ROS-mediated mitochondrial pathway. Free Radic Biol Med 45:60-72

Chu G (1994) Cellular responses to cisplatin. J Biol Chem 269: $787-790$

Dobrzyńska I, Skrzydlewska E, Figaszewski Z (2006) Parameters characterizing acid-base equilibria between cell membrane and solution and their application to monitoring the effect of various factors on the membrane. Bioelectrochemistry 69:142-147

Dobrzyńska I, Skrzydlewska E, Figaszewski Z (2013) Changes in electrical properties of human breast cancer cells. J Membr Biol 246:161-166

Gea Speelmans G, Rutger WM, Staffhorts M, Versluis K, Reedijk J, de Kruiijff B (1996) Cisplatin complexes with phosphatidylserine in membranes. Biochemistry 36:10545-10550

Gennis RB (1989) Biomembranes: molecular structure and functions. Springer, New York
Giaccone G, Herbst RS, Manegold Ch, Scagliotti G, Rosell R, Miller V, Natale RB, Schiller JH, von Pawel J, Pluzanska A, Gatzemeier U, Grous J, Ochs JS, Averbuch SD, Wolf MK, Rennie P, Fandi A, Johnson DH (2004) Gefitinib in combination with gemcitabine and cisplatin in advanced non-small-cell lung cancer: a phase III trialINTACT 1. J Clin Onkol 22:777-784

Krysiński P, Tien HY (1986) Membrane electrochemistry. Prog Surf Sci 23:17-412

Narayanan S (1994) Sialic acid as a tumor marker. Ann Clin Lab Sci 24:376-384

Nicol BM, Prasad SB (2002) Sialic acid changes in Dalton's lymphoma-bearing mice after cyclophosphamide and cisplatin treatment. Braz J Med Biol Res 35:549-553

Oliva JP, Valdes Z, Casaco A, Pimentel G, Gonzales J, Alvarez I, Osorio M, Velanzco M, Figueroa M, Ortiz R et al (2006) Clinical evidences of GM3 (NeuGc) gangliside expression in human breast cancer using the 14F7 monoclonal antibody labeled with (99 m)Tc. Breast Cancer Res Treat 96:115-121

Poplawska B, Bielawska A, Surazynski A, Czarnomysy R, Bielawski K (2009) Novel dinuclear platinum(II) complexes targets NFkappaB signaling pathway to induce apoptosis and inhibit metabolism of MCF-7 breast cancer cells. Folia Histochem Cytobiol 47(5):S141-S146

Rybak LP, Ramkumar V (2007) Ototoxicity. Kidney Int 72:931-935

Sekimizu K (1994) Interactions between DNA replication-related proteins and phospholipids vesicles in vitro. Chem Phys Lipids 73:223-230

Sharma S, Santiskulvong C, Bentolila LA, Rao J, Dorigo O, Gimzewski JK (2012) Correlative nanomechanical profiling with super-resolution F-actin imaging reveals novel insights into mechanisms of cisplatin resistance in ovarian cancer cells. Nanomedicine 8(5):757-766

Szachowicz-Petelska B, Figaszewski Z, Lewandowski W (2001) Mechanisms of transport across cell membranes of complexes contained in antitumour drugs. Int J Pharm 222:169-182

Szachowicz-Petelska B, Dobrzyńska I, Sulkowski S, Figaszewski ZA (2012) Characterization of the cell membrane during cancer transformation. In: Ettarh R (ed) Cancer biology-from genes to tumor. InTech, Croatia, pp 241-256

Szachowicz-Petelska B, Dobrzyńska I, Skrodzka M, Darewicz B, Figaszewski ZA, Kudelski J (2013) Phospholipid composition and electric charge in healthy and cancerous parts of human kidneys. J Membr Biol 246:421-425

Weigelt B, Peterse JL, van't Veer LJ (2005) Breast cancer matastasis: markers and models. Nat Rev Cancer 5:591-602 